\title{
Pediatrik endoskop ile tedavi edilen koledokolitiazis olgusu
}

\section{A case of choledocholithiasis treated with pediatric gastroscope}

Sami ÇIFÇI, Murat BIYIK, Hüseyin ATASEVEN, Ramazan UÇAR, Ali DEMIR, Hakkı POLAT, Özlem ÖZER ÇAKIR Konya Necmettin Erbakan Üniversitesi Meram Tıp Fakültesi Gastroenteroloji Bilim Dal, Konya

Geçirilmiş safra yolu cerrahileri sonrası sık karşılaşılan koledokolitiazis, tanı ve tedavisinde önemli problemler olabilen ciddi bir durumdur. Son yıllarda ultraslim endoskoplar koledokolitiazis tanı ve tedavisinde giderek artan kullanım alanı bulmuştur. Pediatrik endoskop ile tanı ve tedavisi başarılı bir şekilde yapılmış olan 62 yaşında kadın, koledokolitiazis olgusu sunulmuştur.

Anahtar kelimeler: Koledokolitiazis, tedavi, pediatrik gastroskop
Choledocholithiasis is a common disease after bile duct surgery, and there may be problems during the diagnosis and treatment of this serious condition. In recent years, ultra-slim endoscopes have been increasingly used in the diagnosis and treatment of choledocholithiasis. We report the case of a 62-year-old woman who was diagnosed and treated successfully with pediatric endoscope.

Keywords: Choledocholithiasis, treatment, pediatric gastroscope

\section{GİRİS}

Koledokolitiazis ortak safra kanalı içerisinde safra taşı oluşumu olarak adlandırılan bir durumdur. Bu taşlar klasik olarak iki grupta incelenir. Safra yollarında oluşan taşlar primer, safra kesesinde oluşup safra yollarına düşenler ise sekonder taşlar olarak adlandırlır. Primer olarak en sık kahverengi taşlar görülür, bu taşlar sıklıkla bilirübin ve fosfolipitler üzerine bakteriyel enfeksiyonların etkileri ile oluşur. Bu hastalarda sıklıkla proksimal biliyer striktürler ve bununla beraber tekrarlayan kolanjit atakları birlikte bulunur. Koledokolitiazisin gerçek insidansı tam olarak bilinmesede kolesistektomi geçirenlerin yaklaşık \%5 ile 20'sinde ortak kanal taşı olduğu tahmin edilmektedir (1).

Koledokolitiazis tanısında; transabdominal ultrasonografi, endoskopik ultrasonografi, magnetik resonans kolanjiopankreatografi, endoskopik retrograd kolanjiografi (ERCP), intraoperatif kolanjiografi veya ultrasonografi, abdominal kompütorize tomografi ve perkütan transhepatik kolanjiografi gibi çeşitli teknikler kullanılabilir. Tanı degerlendirilmesinde ana hedef en az invaziv, en doğru ve maliyet etkin yöntem olmalidır.

Koledokolitiazis tedavisinde en yaygin kullanılan tedavi yöntemi halen ERCP olup hasta seçimi uygulanacak teknik ve oluşabilecek komplikasyonlar açısından iyi değerlendirilmelidir. ERCP dışında cerrahi tedavi, mekanik litotripsi, ekstrakorporeal şok tedavisi, perkütanöz radyolojik tedaviler ve dissolüsyon tedavileri ek olarak sayllabilir (2).

Son yllarda giderek gündeme gelen peroral kolanjioskopi (POC) yöntemi biliyer hastalıkların hem tanı hem de tedavi-

sinde önemli katkılar sağlamaktadır. Biliyer ağacı direk olarak göstermesi nedeni ile tedavisi zor biliyer taşların, biliyer striktürlerin değerlendirilmesi ve intralüminal lezyonların daha doğru olarak ayırt edilmesine katkı sağlamaktadır (3).

Burada geçirilmiş safra yolu cerrahileri sonrasında tekrarlayan karın ağrıları ile prezente olan ve biliyer taş hastalığı bulunan bir hasta tartışılmış olup, basit endoskopik yöntemler ile tedavinin gerçekleştirilebileceği bir vaka sunulmuştur.

\section{OLGU}

Altmışiki yaşında kadın hasta, yaklaşı 5 yıl önce kolesistektomi hikayesi olan ve sonraki ylllarda ara ara tekrarlayan karın sağ üst kadran ağrısı olan hastada 3 yıl önce karaciğer kist hidatiği ve koledok kisti tespit edilmiş ve bu nedenle opere edilmiş. Bu tarihten sonra hastanın aralıklı birkaç kez daha karın ağrıları ve beraberinde ateş şikayeti olması nedeni ile hospitalize edilmiş. Hasta son olarak hastanemize karın sağ üst kadranda sırta vuran tarzda ağrıları olması nedeni ile başvurdu. Yapilan tetkiklerinde; WBC: 11000 /mlt, CRP: 44 mg mg/L, AST:18, ALT:20 U/L, ALP:194 U/L, GGT: 135 U/L, D. bilirubin: $0,26 \mathrm{mg} / \mathrm{dL}$ tespit edildi. Hastaya tüm batın ultrasonografisi istendi ve karaciğer sol lobda intrahepatik safra yollarında hava ile uyumlu ekojeniteler tespit edildi, koledokta herhangi bir patoloji belirtilmemiş idi. Hastaya bunun üzerine uygun medikal tedavi planlandı ve ERCP hazırlığına başland. ERCP öncesinde safra yolu cerrahisi öyküsü olması nedeni ile üst endoskopi planlandı ve bulbusta koledokoduedonostomi ağzı tespit edildi. Daha sonra olympus CLV 


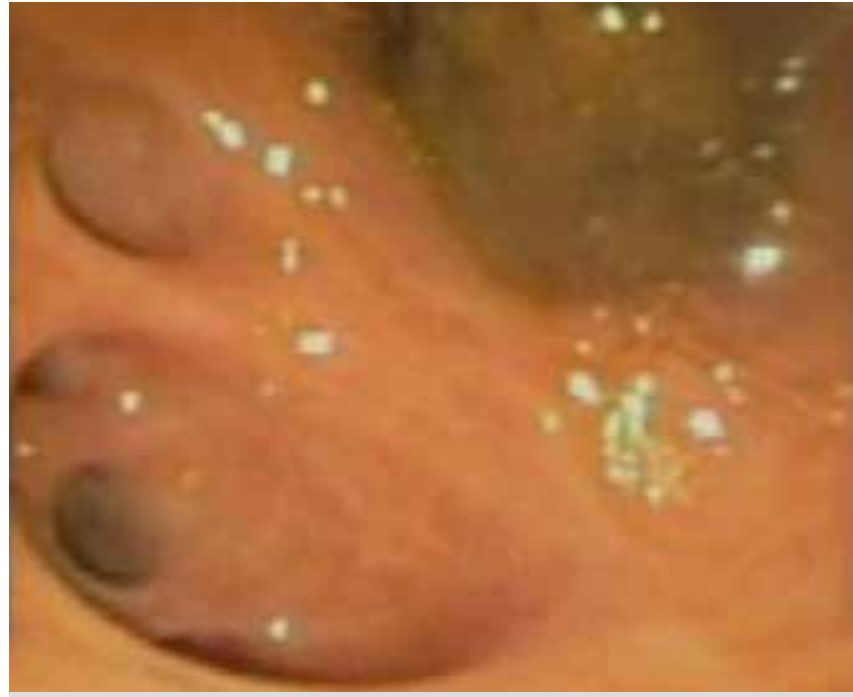

Resim 1. Intrahepatik safra yolu bifurkasyonu ve kanal içerisindeki taş.

180 pediatrik gastroskop ile tekrarlanan girişimde bulbustaki koledokoduedonostomi ağzından girildi ve intrahepatik safra yolu bifurkasyonunda yaklaşık 7-8 mm çapında bir adet taş gözlendi (Resim 1). Fileli polipektomi snare ile taş çıkartıldı ve sonrasinda koledok ve intrahepatik safra yolları steril serum fizyolojik ile yıkandı (Resim 2). Hastanın sonraki takiplerinde medikal tedaviye devam edildi, laboratuvar ve klinik olarak belirgin düzelme olması üzerine taburcu edildi.

\section{TARTISQMA}

ERCP koledokolitiazis tanı ve tedavisinde yaygın olarak kullanılan bir yöntem olup teknik beceri gerektiren invaziv bir yöntemdir. Koledok taşı için sensitivitesi yaklaşık \%80-93, spesifitesi ise yaklaşık \%100'dür (4). Buna karşın invaziv bir yöntem olması nedeni ile bir çok ciddi komplikasyonlar ile ilişkilidir.

ERCP komplikasyonun değerlendirildiği 21 çalışma ve 16855 vakayı içeren derlemede pankreatit, sepsis, kanama ve perforasyon gibi spesifik komplikasyon sayısı $1154(\% 6,9)$ bulunmuş, bunların $55(\% 0,33)$ tanesi ölümle sonuçlanmış (5).

ERCP ile karşılaştırılmıyacak düzeyde komplikasyona sahip olan peroral kolanjioskopi yöntemi günümüzde Amerika Birleşik Devletlerinde yaygın olarak kullanılmaktadır. Teknik olarak ise en sık çift endoskopist ile kullanılan bu yöntem,

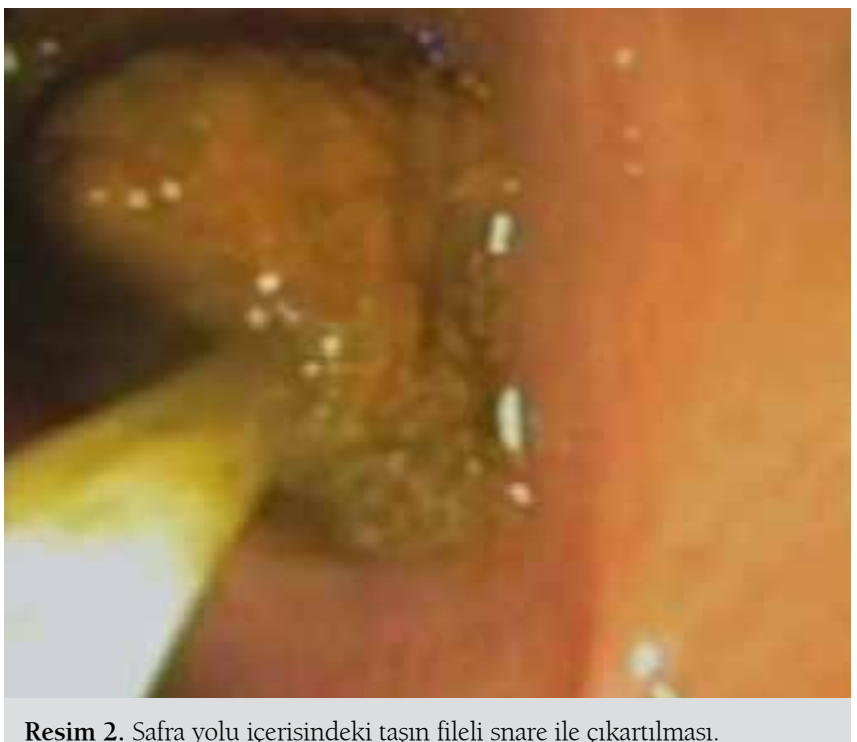

teknik çeşitliliğe sahiptir ve yardımcı aparatlar ile tek endoskopist tarafından da gerçekleştirilebilir (3).

Standart endoskopik yöntemler ile hastaların yaklaşı \% 5 ila 10'unda taşların büyük olması, impakte olması veya stenoz nedeni ile biliyer taşların tam olarak temizlenmesi mümkün olamamaktadır. Bunun gibi tedavisi zor ekstrahepatik biliyer taşların POC ile intrakorporeal litotripsi yöntemleri kullanılarak \%83 ile \%100'ü temizlenebilmektedir $(6,7)$. Intrakorporeal litotripsi yöntemleri günümüzde zor biliyer taşların tedavisinde sıklıkla kullanılmaktadır. Bu yöntemlerden özellikle lazer veya elektrohidrolik yöntemin POC eşliğinde kullanıldığı çok merkezli bir çalışmada \%90'nın üzerinde etkinliğinin olduğu belirtilmektedir (8).

Biliyer taş tedavisi sırasında karşılaşılan güçlükler nedeni ile ERCP'ye alternatif yöntemler her zaman gündemde olmuștur. Hastamızda olduğu gibi minimal invaziv yöntem arayışı nedeni ile pediatrik endoskop kullanılarak direk görüntüleme ile hem kesin tanı konulmuş hemde kolaylıkla tedavisi gerçekleştirilmiştir.

Sonuç olarak uygun vakalarda pediatrik endoskopun bilier hastalıkların tanı ve tedavisinde kullanılabileceğini ve POC'nin daha az invaziv bir yöntem olması nedeni ile ülkemizde gelecekte daha tercih edilir bir yöntem olacağını düşünmekteyiz.

\section{KAYNAKLAR}

1. Praf F, Meduri B, Ducot B, et al. Prediction of common bile duct stones by noninvasive tests. Ann Surg 1999;229:362-8.

2. Williams EJ, Green J, Beckingham I, et al. Guidelines on the management of common bile duct stones (CBDS). Gut 2008;57:1004-21.

3. Parsi MA. Peroral cholangioscopy in the new millennium. World J Gastroenterol 2011;17:1-6.

4. Prat F, Amouyal G, Amouyal P, et al. Prospective controlled study of endoscopic ultrasonography and endoscopic retrograde cholangiography in patients with suspected common bileduct lithiasis. Lancet 1996;347:75-9. 
5. Andriulli A, Loperfido S, Napolitano G, et al. Incidence rates of postERCP complications: a systematic survey of prospective studies. Am J Gastroenterol 2007;102:1781-8.

6. Arya N, Nelles SE, Haber GB, et al. Electrohydraulic lithotripsy in 111 patients: a safe and effective therapy for difficult bile duct stones. Am J Gastroenterol 2004; 99:2330-4.
7. Piraka C, Shah RJ, Awadallah NS, et al. Transpapillary cholangioscopydirected lithotripsy in patients with difficult bile duct stones. Clin Gastroenterol Hepatol 2007;5:1333-8.

8. Parsi MA, Neuhaus H, Pleskow D, et al. Peroral cholangioscopy guided stone therapy-report of an international multicenter registry. Gastrointest Endosc 2008;67:AB102. 